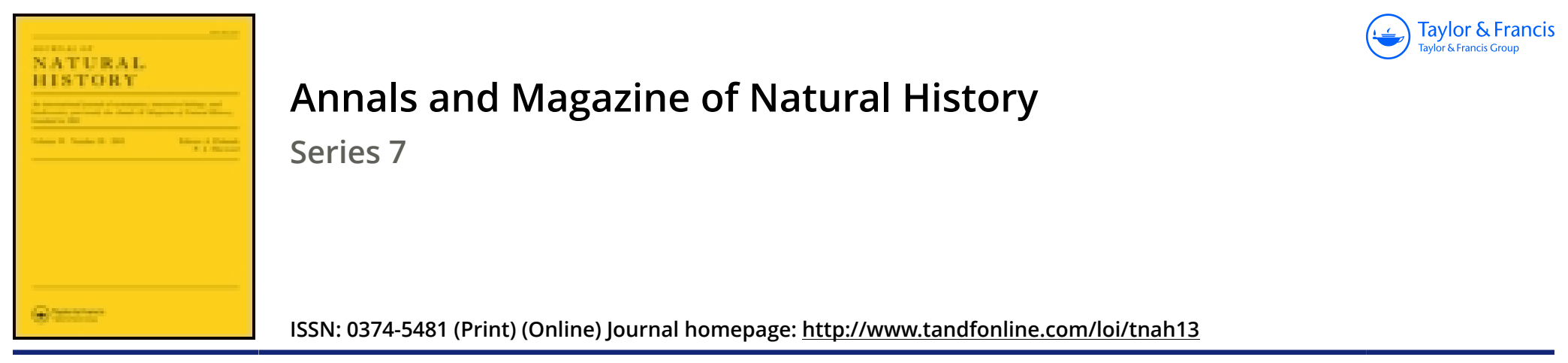

\title{
LIV.-Descriptions of some new species of Lepidoptera from East Africa and Tropical America
}

\section{Herbert Druce F.L.S.}

To cite this article: Herbert Druce F.L.S. (1901) LIV.-Descriptions of some new species of Lepidoptera from East Africa and Tropical America, Annals and Magazine of Natural History, 7:41, 432-444, DOI: 10.1080/00222930108678495

To link to this article: http://dx.doi.org/10.1080/00222930108678495

\section{Published online: 28 Sep 2009.}

\section{Submit your article to this journal $\sqsubset$}

Џ Article views: 4

Q View related articles $\square$

Citing articles: 2 View citing articles $\square$ 
Cletus clarus, Walk, loc. cit. p. 190. n. 15,= Plinacthus dubius, H.-S.

mundus, Walk, loc. cit. p. 191 . n. 17,= Plinacthus spinosus, Stal.

—_ signatus, Walk. loc. cit. p. 194. n. 39, = Cletus bipunctatus, Westw.

- pallescens, Walk. loc cit. p. 195. n. $40,=$ Cletus rubidiventris, Westw.

— ? indecorus, Walk. loc. cit. p. 197. n. $45,=$ Clavigralla horrens, Dohrn?

- conspicuus, Walk. loo. eit. p. 198. n. 47,=Plinacthus acicularis, Fabr.

Namacus rufescens, Walk. loc. cit. $\nabla$. p. 1. n. $2(1872),=$ Namacus annulicornis, Stål.

\section{To be treated as non-existent.}

Species the types of which are not now to be found in the British Museum.

Paryphes viridipes, Walk. Cat. Het. iv. p. 88. n. 13 (1871).

Jadera abdominalis, Walk. loc. cit. p. 145. n. 6.

Cletus apicifer, Walk, loc. cit. p. 195, n. 41.

Clavigralla spinigera, Walk. loc. cit. v. p. 6. n. 22 (1872).

dispar, Walk. loc. cit. n. 23.

\section{Wrongly included in the Coreidæ.}

Serinetha antica, Walk. Cat. Het. iv. p. 147 (1871), belongs to gen. Astacops (Lygaida).

— spurcata, Walk. loc. cit., belongs to gen. Astacops (Lygaida).

- fascicollis, Walk. loc. cit., " " " ",

— turbata, Walk. loc. cit. p. 148, " " "

Dulichius ? clavifer, Walk. loc. cit. p."170, n. 2, belongs to gen. Helopeltis (Capside).

Noliphus? muficollis, Walk. loc. cit. iv. p. 176. n. 5 (1871), belongs to fam. Capside.

? distinctus, Walk. loc. cit. n. 6, belongs to fam. Lygaide.

_._? biplagiatus, Walk. loc. cit. p. 177. n. 7, " " ",

Verlusia rhombea, Kirby (nec Linn.), Journ. Linn. Soc., Zool. xxiv. p. 92 (1894).

Mr. Kirby included a "single immature specinen" from Ceylon as "apparently belonging to this common European species." It must, however, be placed in the family Phymatidæ.

LIV.-Descriptions of some new Species of Lepidoptera from East Africa and Tropical America. By Herbert Druce, F.L.S. \&c.

Fam. Hesperiidæ.

Parosmodes numa, sp. $\mathbf{n}$.

Male.-Head, antennæ, thorax, and abdomen on the upperside black; underside of the thorax, abdomen, and legs 
greyish brown. Primaries black; a yellowish-brown spot at the end of the cell, one beyond on the costal margin from which a series of small spots extends across the wing to the inner margin ; the fringe yellowish brown : secondaries black; a small yellowish-brown spot at the end of the cell, below which a wide yellowish-brown band crosses the wing from the anal angle almost to the inner margin; the fringe yellow. Underside: primaries very similar to the upperside, but much browner in colour: secondaries reddish brown, crossed from the costal to the inner margin by two very indistinct redder brown bands, the wing slightly irrorated with small reddish spots.-Female very similar to the male, but blacker.

Expanse, $\delta \&, 1 \frac{1}{10}$ inch.

Hab. East Africa, Dar-es-Salaam (Mus. Druce)

This species is allied to Parosmodes icteria, Mab.

\section{Fam. Agaristidæ.}

\section{Xanthospilopteryx melanosoma, sp. $\mathrm{n}$.}

Male.-Head, antennæ, collar, tegulæ, thorax, and abdomen black; the collar and thorax spotted with white; a tuft of yellow hair at the base of the abdomen; a row of white spots down the middle and on each side of the abdomen; the legs black, banded with orange and white. Primaries black, with three small bluish-white dots on the costal margin close to the base; two yellow spots nearest the base, one at the end of the cell and one below extending almost to the anal angle, above which a curved yellow band, becoming narrow near the costal margin; the veins crossing the band are black: secondaries orange-red, darkest from the middle to the inner margin; the apex and outer margin bordered with black nearly to the anal angle. Underside: primaries bright yellow, the costal margin, apex, and outer margin black; a large black mark at the end of cell, a round black spot in the cell, and an indistinct black spot below the cell: secondaries very similar to the upperside, but paler in colour.

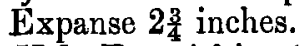

Hab. East Africa (Mus. Druce).

\section{Fam. Arctiidæ.}

\section{Eucyane hermoea, sp. $\mathrm{n}$.}

Male.-Head, palpi, antennæ, collar, tegulæ, and thorax black, the collar and tegulæ irrorated with metallic-green scales; abdomen above blue, dark brown on the underside, 
banded with red. Primaries very similar to those of $E$. excellens, Walk., but greener, the white band narrower and without any red spot at the anal angle; the fringe not white at the apex : secondaries darker blue than in E. excellens and without the red spot on the costal margin.-Female very similar to the male, but rather larger.

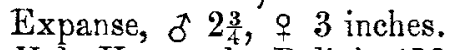

Hab. Venezuela, Bolivia (Mus. Druce).

Eucyrta lucens, sp. n.

Head and collar yellow; tegulæ white, edged with yellow at the base; thorax white, spotted with black; antennæ black; abdomen above bright red; the underside, anus, and legs white; a row of white spots extends from the base of the abdomen to the anus. Primaries and secondaries pure white; a black spot at the end of the cell on the costal margin, two close to the apex, and two at the anal angle.

Expanse $1 \frac{1}{2}$ inch.

Hab. Colombia, Don Amo (Mus. Druce).

This species is allied to $E$. daga, Dogn.

\section{Neritos blanda, sp. n.}

Male.-Head, antennæ, collar, tegulæ, and thorax pinkish fawn-colour; abdomen above bright red, the underside, legs, and anus white. Primaries pinkish fawn-colour, crossed about the middle from the costal to the inner margin by a curved indistinct brown band; a small pink spot on the brown band close to the inner margin, a small black dot close to the base, the apex, outer and inner margin partly edged with pink : secondaries semihyaline bright pink, the fringe white.

Expanse $1_{1}^{3} \overline{0}$ inch.

Hab. Colombia, Don Amo (Mus. Druce).

This species is allied to $N$. asana, Druce.

\section{Elysus chrysellus, sp. n.}

Male.-Head, collar, and thorax chrome-yellow, tegulæ brown, antennæ dark brown, abdomen and legs reddish brown, anus yellow. Primaries chrome-yellow, the veins and a number of small spots at the base and at the end of the cell bright red; a brownish-red band crosses the wing near the base, and a submarginal brown band edged with red extends from close to the apex to the anal angle; the fringe alternately yellow and brown: secondaries pinkish yellow, the fringe yellow.

Expanse 1 $1 \frac{1}{2}$ inch.

Hab. Colombia, Don Amo (Mus. Druce). 
Fam. Limacodidæ.

Dalcera necoda, sp. $\mathrm{n}$.

Male.-Head, antennæ, collar, tegulæ, thorax, abdomen, and legs yellowish white. Primaries pale fawn-colour, darkest at the apex and round the outer margin; a reddish fawn-coloured spot at the end of the cell, from which two faint brown lines extend nearly to the anal angle; a minute black dot about the middle of the inner margin : secondaries pale fawn-colour, palest at the base, the fringe whitish.Female very similar to the male, but larger and almost white.

Expanse, o $\frac{3}{4}$, o $1_{1}^{\frac{3}{0}}$ inch.

Hab. Colombia, Don Amo (Mus. Druce).

This species is allied to $D$. ampela, Druce.

\section{Euclea (?) punctata, sp. n.}

Male-Head, antennæ, and collar pale brown; thorax, abdomen, and legs white. Primaries white, the base, costal margin, and inner half of the wing thickly spotted with pale brown; the fringe alternately brown and white: secondaries pure white, the fringe white.

Expanse 1 inch.

Hab. Colombia, Bonda (Mus. I)ruce).

Fam. Cossidæ.

\section{Duomitus daphne, sp. $\mathrm{n}$.}

Male.-Head and antennæ dark brown; collar, tegulæ, and thorax greyish brown; abdomen and legs dark brown. Primaries pale greyish brown, thickly mottled with dark brown; a dark brown spot in the cell, three below the cell, and two close to the apex; the marginal line dark brown: secondaries dark greyish brown.

Expanse $1 \frac{3}{4}$ inch.

Hab. Colombia, Minca (Mus, Druce).

\section{Duomitus striatus, sp. $\mathrm{n}$.}

Male.-Head, collar, tegulæ, and thorax blackish grey; antennæ yellow; abdomen grey-black, paler at the base and anus. Primaries dark grey, darkest at the base and along the costal margin: secondaries dark grey; both wings are thickly striated with very fine dark grey lines.

Expanse $1 \frac{1}{2}$ inch.

Hab. Colombia, Cacagualito (Mus. Druce). 


\section{Langsdorfia Buckleyi, sp. $\mathrm{n}$.}

Male.-Head, collar, tegulæ, thorax, abdomen, and legs dark brown; antennæ blackish brown. Primaries dark brown; a large reddish-brown broken band crosses the wing near the base; a large metallic gold spot just above the inner margin; a square-shaped reddish-brown spot below the cell; a dark brown spot edged with white close to the apex; some fine white lines along the outer margin; the fringe dark brown : secondaries dark brown, very mottled on the underside with darker brown.

Expanse 2 inches.

Hab. Ecuador, Sarayacu (Mus. Druce).

\section{Langsdorfa rufescens, sp. $\mathbf{n}$.}

Male.-Head, antennæ, collar, tegulæ, thorax, abdomen, and legs reddish brown. Primaries reddish brown, crossed about the middle from the costal to the inner margin by a narrow white line, the outer edge of the white line bordered with a dark reddish-brown band; the wing above the anal angle greyish : secondaries reddish brown.

Expanse $1 \frac{1}{4}$ inch.

Hab. Colombia, Bonda (Mus. Druce).

\section{Zeuzera ceetes, sp. n.}

Male.-Antennæ yellow; head, collar, underside of the thorax, legs, and underside of the abdomen dark brown; tegulæ and thorax white; abdomen pale brown. Primaries: the costal half of the wing pale brown, the costal margin dark brown; the inner half of the wing white, striated with fine dark brown lines; a rather wide short brown streak below the cell : secondaries white.

Expanse 2 inches.

Hab. Colombia, Bonda (Mus. Druce).

\section{Fam. Hepialidæ.}

\section{Hepialus prosopus, sp. n.}

Head, antennæ, collar, tegulæ, thorax, abdomen, and legs reddish brown, the abdomen paler above. Primaries pale reddish fawn-colour, mottled with darker brown, the inner part of the wing near the base pinkish; three broken greyish bands cross the wing beyond the middle from the costal to 
the inner margin; the fringe dark brown: secondaries pale pinkish brown.

Expanse 3 inches.

Hab. Colombia, Bonda (Mus. Diuce).

Allied to $H$. momus, Druce.

\section{Dolaca thisbe, sp. $\mathbf{n}$.}

Male.-Head, antennæ, collar, tegulæ, thorax, and abdomen dark brown; the underside of the abdomen yellowish brown; the legs dark brown. Primaries yellowish brown, darkest along the costal margin; a metallic gold spot on the inner margin near the base; a row of metallic gold spots crosses the wing beyond the middle from near the costa to the inner margin; two gold spots beyond the cell, and a marginal row of gold dots extend from the apex to the anal angle; the fringe brown: secondaries uniformly pale brown.

Expanse $1 \frac{1}{2}$ inch.

Hab. Colombia, Don Amo (Mus. Druce).

Fam. Notodontidø.

Rifargia nubila, sp. n.

Male.-Head, antennæ, collar, tegulæ, thorax, and abdomen pale greyish brown; the underside of the thorax, abdomen, and legs cream-colour. Primaries very pale brown, crossed near the base from the costal to the inner margin by a rather wide greyish-brown band; a dark brown spot close to the base and a larger round dark brown spot at the end of the cell, above which is a smaller spot of the same colour; a submarginal brown line extending from the apex to the anal angle : secondaries brownish white, the outer margin bordered with brown from the apex to the anal angle-Female very similar to the male, but darker in colour; the secondaries dark reddish brown, with the fringe yellowish; the underside is also very much darker than in the male.

Expanse, of 1, $+1 \frac{1}{2}$ inch.

Hab. Colombia, Don Amo (Mus. Druce).

Heterocampa corda, sp. $\mathrm{n}$.

Male.-Head and antennæ pale brown; collar and tegulæ dark brown; thorax silvery grey; abdomen brown, slightly yellowish at the base, the anal segments grey. Primaries silvery grey, thickly irrorated with brown; two black dots at the end of the cell and two below the cell; a wide waved 
brown submarginal band edged with white crosses the wing from the costal margin near the apex to the anal angle; fringe grey: secondaries dark brown, the fringe alternately grey and brown.

Expanse $1 \frac{3}{4}$ inch.

Hab. Colombia (Mus. Druce).

Subfam. STICTOPTERINE.

Stictoptera creta, sp. n.

Male.-Head, antennæ, collar, tegulæ, thorax, and abdomen pale brown; legs brown. Primaries pale brown, crossed from the costal to the inner margin by very fine greyishwhite lines; a wide black band edged with white on the inner side crosses the wing about the middle from the costal to the inner margin, where it is slightly wider : secondaries pure white, broadly bordered with pale brown.

Expanse $1 \frac{1}{2}$ inch.

Hab. Colombia, Don Amo (Mus. Druce).

Fam. Deltoidæ.

Hypena divergens, sp. $\mathrm{n}$.

Male.-Head, antennæ, palpi, thorax, abdomen, and legs black. Primaries black; a narrow pale yellow band crosses the wing from the middle of the costal margin to the anal angle: secondaries black, the costal margin edged with yellow, the fringe black. Underside similar to the upperside, but much browner, and the yellow band on the primaries three times as wide.

Expanse 1 inch.

Hab. Bolivia (Garlepp, Mus. Druce).

Bypena vitula, sp. $\mathrm{n}$.

Male-Head, antennæ, palpi, thorax, and abdomen brown. Primaries dark brown; a pale brown indistinct waved line crosses the wing at the end of the cell from the costal to the inner margin; two black dots edged with white in the cell; a submarginal row of indistinct greyish dots extends from the apex to the anal angle; a marginal row of pale brown points; the fringe dark brown: secondaries white, clouded with brown from the apex to the anal angle and along the inner margin; the fringe dark brown. Underside: primaries very similar to the upperside, but rather paler in colour; 
secondaries dark brown, with a central brown band and a black spot in the cell.

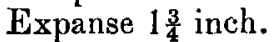

Hab. Ecuador, Sarayacu (Buckley, Mus. Druce).

\section{Hypena leucoptera, sp. n.}

Male.-Head, palpi, and thorax pale brown; antennæ and abdomen dark brown. Primaries dark brown, the base, inner margin, and a rather wide band crossing the wing to the inner margin all pale pinkish brown: secondaries white, broadly bordered with dark brown from the apex to the anal angle. Underside of the primaries pale brown, with a small white spot close to the anal angle.

Expanse $1 \frac{1}{2}$ inch.

Hab. Peru (Mus. Druce).

\section{Hypena lyse, sp. n.}

Male.-Head, antennæ, palpi, thorax, and abdomen pale brown. Primaries pale brown, with a large central brown mark, edged with a fine yellowish-brown line, much dentated on the outer side; a submarginal row of very indistinct dark brown spots crosses the wing from the apex to the anal angle; the fringe dark brown: secondaries white, the apex, outer and inner margin broadly bordered with dark brown.

Expanse $1 \frac{3}{4}$ inch.

Haz. Ecuador, Chiguenda (Buckley, Mus. Druce).

\section{Hypena melaleuca, sp. $\mathrm{n}$.}

Male.-Head, antennæ, palpi, thorax, and abdomen pale brown. Primaries pale brown, crossed from the costal to the inner margin by several very indistinct, narrow, waved, darker brown lines; a very dark brown band extends from the base to the anal angle; two small white dots close to the apex; the fringe dark brown : secondaries white, broadly bordered with black from the apex to the angle, the inner margin slightly black.

Expanse 2 inches.

Hab. Bolivia (Garlepp, Mus. Druce).

Fam. Tortricidæ.

Atteria Buclileyi, sp. n.

Male.-Head, antennæ, palpi, collar, thorax, abdomen, and legs black; tegulæ black, edged with yellow. Primaries 
dark blue, the costal, outer, and inner margins streaked with orange-yellow; a row of orange-yellow spots down the middle of the wing; the fringe alternately dark blue and orangeyellow : secondaries brownish black, crossed from the costal margin by four rows of orange-yellow spots; the fringe black.

Expanse $1 \frac{1}{4}$ inch.

Hab. Ecuador, Intaj (Buckley, Mus. Druce).

\section{Atteria maon, sp. n.}

Male.-Head, antennæ, thorax, and abdomen black; collar and tegulæ yellow; palpi yellow, the third joint black; legs black, banded with yellow. Primaries chrome-yellow, crossed from the costal to the inner margin by bands of dark blue spots, the outer margin streaked with dark blue ; the fringe black : secondaries chrome-yellow, thickly spotted with dark blue; the fringe black.

Expanse 1 inch.

Hab. Ecuador, Chiguinda (Buckley, Mus, Druce).

\section{Atteria splendens, sp. n.}

Male.-Head orange, palpi and antennæ black, collar orange, tegulæ orange spotted with black ; thorax, abdomen, and legs orange, the anal segment of the abdomen black. Primaries orange-red; the costal margin and the outer half of the wing creamy white, broadly banded with black; the fringe alternately black and white: secondaries orange-red, the apex broadly black; two black spots on the outer margin.

Expanse $1_{10}^{3}$ inch.

Hab. Ecuador, Sarayacu (Buckley, Mus. Druce).

Allied to $A$. mimica, Feld. \& Rog., and A. volcanica, Butler.

Atteria lydia, sp. n.

Male.-Head, antennæ, collar, tegulæ, thorax, abdomen, and legs black; palpi, the first and third joints black, the second joint orange-yellow. Primaries very dark blue, crossed from the costal to the inner margin before the end of the cell by three waved orange-yellow bands; a round orangeyellow spot at the end of the cell, beyond which is a curved orange subinarginal line; the apex and outer margin streaked with orange-yellow; the fringe dark brownish yellow: secondaries brown, the costal margin yellow; a black spot at the end of the cell.

Expanse 1 inch.

Hab. Ecuador, Chiguinda (Buckley, Mus. Druce). 
Fam. Tineidæ.

Subfam: Arophorinse.

Ankistrophorus giganteus, sp. $\mathrm{n}$.

Female-Head, antennæ, palpi, and thorax reddish brown; abdomen darker brown; legs brown. Primaries reddish brown, irrorated with darker brown streaks along the costal margin and the outer half of the wing; the fringe reddish brown : secondaries very similar to the primaries in colour but slightly darker, the fringe pale reddish brown.

Expanse $2 \frac{3}{10}$ inches.

Hab. Mexico, Orizaba (Boucard, Mus. Druee).

Thysanosedes Salvini, sp. n.

Male--Head, palpi, thorax, abdomen, and legs very pale fawn-colour; antennæ yellow. Primaries pale fawn-colour, slightly irrorated along the costal margin and at the apex with a few brown scales : secondaries pale fawn-colour; the fringes of both wings pale fawn-colour.-Female darker than the male, but in all other respects very similar.

Expanse, o* 1, o $1 \frac{3}{10}$ inch.

Hab. Panama, Obispo (Salvin, Mus. Druce).

Acrolophus linus, sp. n.

Male--Head, antennæ, thorax, and abdomen dark brown; palpi dark brown, paler on the inner side; legs pale brown. Primaries dark brown, irrorated with greyish scales; a dark brown mark about the middle of the wing; the outer margin pale brown; the fringe dark brown : secondaries pale whitish brown.

Expanse 1 inch.

Hab. Mexico, Orizaba (Boucard, Mus. Druce).

Acrolophus Boucardi, sp. n.

Male--Head, antennæ, thorax, abdomen, and legs pale brown; palpi greyish brown. Primaries dark brown, striated along the costal margin with pinkish brown; the base of the wing and two large spots on the inner margin pinkish brown, the outer margin pale brown; the fringe alternately dark and light brown: secondaries pale brown; the fringe yellowish brown.-Female very similar to the male, but altogether much greyer.

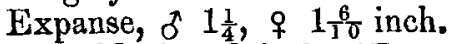

Hab. Mexico, Orizaba (Boucard, Mus. Druce). Ann. \& Mag. N. Hist. Ser. 7. Vol. vii. 


\section{Acrolophus (?) Underwoodi, sp. n.}

Male.-Head, antennæ, palpi, and thorax dark brown; abdomen pale greyish brown. Primaries brown, with a blackish-brown streak from the base of the wing to beyond the middle; the costal margin clouded with blackish brown; a submarginal row of dark brown dots extends from the apex to the inner margin close to the anal angle; the marginal line black; the frirge brown: secondaries pale brownish white, palest at the base and along the costal margin; the fringe greyish brown.

Expanse 1 inch.

Hab. Costa Rica, Candelaria Mts. (Underwood, Mus. Druce).

\section{Anaphora numidia, sp. n.}

Male.-Head, antennæ, palpi, and thorax very dark brown, almost black; abdomen and legs pale brown. Primaries dark brown, lightest near the apex; a triangular-shaped black spot about the middle of the inner margin, above and beyond a square-shaped black spot, the costal margin striated with black lines; the fringe dark brown: secondaries reddish brown.

Expanse $1 \frac{1}{2}$ inch.

Hab. Mexico, Orizaba (Boucard) ; Guatemala (Boucard, Mus. Druce).

$$
\text { Anaphora Arcéi, sp. } 1 .
$$

Male.-Head, antennæ, palpi, and thorax reddish brown; abdomen blackish brown. Primaries dark reddish brown, the inner margin fawn-colour; a fawn-coloured streak extends from the apex to the middle of the wing; the firinge dark brown : secondaries pale reddish brown.-The female differs from the male in not having any of the pale markings on the primaries.

Expanse, of $1 \frac{1}{4}$, o 1 inch.

Hab. Panama, Chiriqui (Arcé, Mus. Druce).

\section{Anaphora libitina, sp. n.}

Male.-Head, antennæ, palpi, thorax, and abdomen creamcolour. Primaries cream-colour, clouded about the middle with dark brown; a few dark brown scales near the apex: secondaries cream-colour, the fringe brownish.-Female very similar to the male, but the secondaries darker brown.

Expanse, o 1 , o $1 \frac{1}{4}$ inch.

Hab. Guatemala, 5000 feet (Salvin, Mas. Druce). 


\section{Anaphora punctata, sp. n.}

Male.-Head, antennæ, palpi, thorax, and abdomen pale brown; legs brownish white. Primaries pale brown, thickly irrorated with dark brown scales; a black dot at the end of the cell and a curved line of black spots from the apex to the base of the wing, the spots near the base are the largest; fringe dark brown: secondaries reddish brown, the fringe rather darker.

Expanse $1 \frac{1}{10}$ inch.

Hab. Costa Rica (Van Patten); Candelaria Mts. (Underwood, Mus. Druce).

\section{Anaphora Whitelyi, sp. n.}

Male--Head, thorax, and abdomen pale brown; antennæ and palpi yellowish brown. Primaries yellowish brown, with a large, central, $V$-shaped, reddish-brown mark extending across the middle of the wing from the costal to the inner margin; the costal margin and the outer margin are striated with reddish brown; a reddish-brown dot on the inner margin close to the base : secondaries blackish brown.

Expanse 1 inch.

Hab. British Guiana, Essequibo River (Whitely, Mus. Druce).

\section{Anaphora Perrensi, sp. n.}

Male-Head, antennæ, palpi, thorax, and abdomen pale brown, the palpi slightly lighter on the inner side. Primaries pale reddish brown, with a central dark brown streak extending from the base to about the middle of the wing; a curved brown line extends from the costal margin to the anal angle, the apical part of the wing being the palest in colour: secondaries pale reddish brown.-The female very similar to the male, but darker in colour.

Expanse, $\delta \frac{3}{4}$, $\& 1 \frac{1}{4}$ inch.

Hab. Brazil, Goya (Perrens, Mus. Druce).

\section{Felderia echinon, sp. $\mathbf{n}$.}

Male.-Head, thorax, palpi, and abdomen dark brown, palpi tipped with white; antennæ yellowish brown; the anus pale brown. Primaries pale brown, the veins all dark brown; two greyish-white spots above the inner margin; the fringe pale brown: secondaries very pale brown, the inner margin slightly darker.

Expanse 1 inch.

Hab. Mexico, Orizaba (Boucard, Mus. Druce). 


\section{Felderia Garleppi, sp. n.}

Male.-Head, thorax, and abdomen dark brown; antennæ pale yellowish brown; palpi dark brown, pale on the inner side. Primaries pale brown, with an indistinct paler band crossing the wing from the apex to the middle of the inner margin; the costal margin striated with dark brown; a long black streak at the end of the cell and one below nearer the base of the wing: secondaries dark blackish brown.

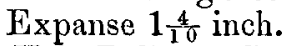

Hab. Bolivia (Garlepp, Mus. Druce).

\section{LV.-On Sciurus notatus and allied Species. By J. L. Bonнote, B.A.}

This group of laterally lineated squirrels is one in which considerable confusion exists. The confusion has been augmented by the existence of two forms, the one having red or yellow underparts, and the other grey underparts; they are frequently found in the same localities, and have generally been regarded as dimorphic forms of a single species.

The name $S$. notatus, which was applied by Boddaert in his 'Elenchus Animalium' to Pennant's description of the "Plantane Squirrel," has to be restricted to a small and light-coloured species inhabiting Java and Sumatra. Raffles's name $S$. vittatus belongs to a very variable species found in Sumatra, the Malay Peninsula, and Borneo; while to the form with grey underparts, hitherto considered specifically identical with the above, and which is found in Java, Sumatra, the Malay Peninsula, and Borneo, Horsfield's name of S. nigrovittatus should be applied.

The following is a list of the species and subspecies of this group :-

Sciurus notatus typicus . . Java.

Hab.

Sciures notalus ypicus. . . Acheen, Sumatra.

_- vittatus typicus . . . Sumatra and Malay Peninsula. - - tenuirostris . . Tioman Island, off Malay

___ anambensis . . Anambas Islands.

- $A b b o t t i$. . Big Tambelan Island, South China Sea.

—- dulitensis . . Borneo. 